\title{
Intraspecific chemical variability of the leaf essential oil of Juniperus phoenicea subsp. turbinata from Corsica
}

\section{Serge Rezzi ${ }^{\mathrm{a}}$, Carlos Cavaleiro ${ }^{\mathrm{b}}$, Ange Bighelli $^{\mathrm{a}}$, Ligia Salgueiro ${ }^{\mathrm{b}}$, António Proença da Cunha ${ }^{\mathrm{b}}$, Joseph Casanova ${ }^{\mathrm{a}, *}$}

${ }^{a}$ Université de Corse, Equipe Chimie et Biomasse, URA CNRS 2053, Route des Sanguinaires, 20000 Ajaccio, France

${ }^{\mathrm{b}}$ Universidade de Coimbra, Faculdade de Farmácia, C.E.F./Laboratório de Farmacognosia, Rua do Norte, 3000 Coimbra, Portugal

Received 4 August 1999; accepted 18 October 1999

\begin{abstract}
The composition of 50 samples of essential oil of individual plants of Juniperus phoenicea subsp. turbinata from Corsica was investigated by GC, GC-MS and ${ }^{13} \mathrm{C}$ NMR. $\alpha$-Pinene, $\beta$-phellandrene, $\alpha$-terpinyl acetate, $\Delta$-3-carene, myrcene and $\alpha$-phellandrene were found to be the main constituents. The results were submitted to cluster analysis and discriminant analysis which allowed two groups of essential oils to be distinguished with respect to the content of $\alpha$-pinene, $\beta$-phellandrene and $\alpha$-terpinyl acetate. (C) 2001 Elsevier Science Ltd. All rights reserved.
\end{abstract}

Keywords: Juniperus phoenicea subsp. turbinata; Cupressaceae; Essential oil; GC; GC-MS; ${ }^{13}$ C NMR; Statistical analysis; Intraspecific variability

\section{Introduction}

The genus Juniperus consists of approximately 60 species growing in the Northern Hemisphere and divided into three sections: Caryocedrus, Juniperus ( = Oxycedrus) and Sabina, the third being the most important one which comprises Juniperus

* Corresponding author. Tel.: + 33-4-95-52-41-21; fax: + 33-4-95-52-41-42.

E-mail address: casanova@vignola.univ-corse.fr (J. Casanova). 
phoenicea L. Recently, Adams (1999) showed on the basis of essential oil composition and RAPD DNA fingerprinting that $J$. phoenicea is distinguishable from other species of section Sabina.

$J$. phoenicea L. (Cupressaceae) is a shrub or a small tree from the Mediterranean region (Bonnier and Douin, 1990). Two subspecific taxa are clearly defined considering distinctive botanical features - not always well conspicuous - and phytogeographic distribution: $J$. phoenicea subsp. phoenicea L. characterized by globose female cones and obtuse or subacute scale-leaves, occurring in the inner mainlands and Juniperus phoenicea subsp. turbinata (Guss.) Parl. Nyman. ( = J. phoenicea subsp. lycia Auct. $=$ J. turbinata Guss.) having elongated female cones and acute scale-leaves, occurring in coastal sites (Franco, 1964). According to phytogeographical repartition (Franco, 1964; Paradis, 1991) only the second subspecies grows wild in Corsica.

There is some controversy in the intraspecific treatment of $J$. phoenicea. Several local forms or biochemical pattern types were reported as subspecies or varieties, such as J. phoenicea subsp. eu-mediterranea Lebr. \& Tiv. based on the prodelphinidine/procyanidine ratio in leaves (Lebreton and Thivend, 1981; Lebreton, 1983) but treated by Adams et al. (1996) as conspecific with $J$. phoenicea subsp. turbinata.

Essential oil of $J$. phoenicea is obtained by hydrodistillation of leaves, fruits or wood. There are few reports on the composition of J. phoenicea leaf oil, even though they concerned plants from various origins and a limited number of samples were analysed every time. The first studies date back to 1956 and 1973 and reported monoterpene-rich oils (subspecies not reported) (Gil de Meister and Hoffman, 1956; Banthorpe et al., 1973). More recently, Vidrich and Michelozzi (1993) reported 1,8-cineole, $\alpha$-pinene and borneol as major components for an oil from Italy (subspecies not reported). Adams et al. (1996) studied samples from different origins and different subspecies. They reported the following compositions: $\alpha$-pinene for $J$. phoenicea (sensu stricto) from inland Greece and Spain and $\alpha$-pinene $/ \beta$-phellandrene $/ \alpha$ terpinyl acetate for $J$. phoenicea var. turbinata from coastal Spain and J. phoenicea subsp. eu-mediterranea from coastal Portugal. In this study the authors emphasized the similarity of the essential oil composition of var. turbinata and subsp. eu-mediterranea and suggested that these taxa are conspecific.

$J$. phoenicea berry oils are characterized by a high content of $\alpha$-pinene, whatever the origin (Fernandes-Costa and Cardoso do Vale, 1953-1954; Gil de Meister and Hoffman, 1956; Proença da Cuhna et al., 1977; De Pascual Teresa et al., 1981; Vidrich and Michelozzi, 1993; Falchi Delitala, 1980; Lawrence, 1989). The wood oil contains thujopsene and cedrol as major components (Adams, 1991), whereas pyrolitic oil is characterized by the predominance of $\alpha$-cedrene (Chalchat et al., 1990). In addition, acidic and neutral diterpenes (Tabacik and Poisson, 1971; Tabacik and Laporthe, 1971; De Pascual Teresa et al., 1978a,b; Dawidar et al., 1991; San Feliciano et al., 1988, 1992, 1993) have been identified in solvent extracts of leaves and berries of $J$. phoenicea.

It appears from literature data that leaf oil of $J$. phoenicea has several compositions. Conversely, the $\alpha$-pinene $/ \beta$-phellandrene $/ \alpha$-terpinyl acetate composition was the only one reported for $J$. phoenicea subsp. turbinata. The purpose of this study was to determine if the same composition was obtained from $J$. phoenicea subsp. turbinata 
from Corsica and to investigate if chemical variability occurred on the well-delimited territory of the island. We planned to collect individual plants from locations covering the geographic range of $J$. phoenicea subsp. turbinata in Corsica.

\section{Materials and methods}

\subsection{Plant material}

$J$. phoenicea subsp. turbinata grows wild in different locations in Corsica as reported by Paradis (1991). In order to study the chemical variability of leaf oils in a delimited area with constant pedoclimatic conditions, we collected 10 samples of single plants in the three most important stations (Fig. 1): Barcaggio (samples 1-10), Bonifacio (11-20), Ajaccio (21-30). Twenty samples were collected in the other locations (Fig. 1): Porto-Vecchio (31-38), Campomoro (39-43), west side of Cape Corsica (44-50). So, all the locations were investigated.

\subsection{Sampling and leaf essential oils}

Leaves were collected from many parts around and at different heights of the plants during the period of May-September, 1998 and submitted to hydrodistillation for $3 \mathrm{~h}$

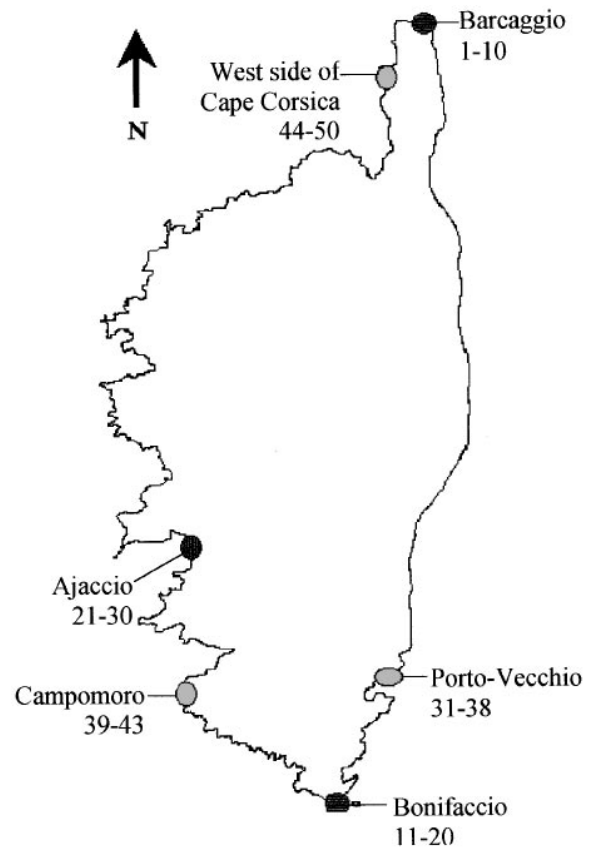

Fig. 1. Sampling of Juniperus phoenicea subsp. turbinata leaves from Corsica (dark grey: the three most important locations; light grey: other locations). 
using a Clevenger-type apparatus. Essential oil yield, ranged between 0.1 and $0.7 \%$ (w/w, from fresh material).

\subsection{GC, GC/MS and Carbon-13 NMR analyses}

Analytical GC: GC analysis was performed using a Perkin-Elmer Autosystem apparatus equipped with two flame ionization detectors (FID), and fused capillary columns $(50 \mathrm{~m} \times 0.22 \mathrm{~mm}$ i.d., film thickness $0.25 \mu \mathrm{m})$, BP-1 (polydimethylsiloxane) and BP-20 (polyethyleneglycol). The oven temperature was programmed from 60 to $220^{\circ} \mathrm{C}$ at $2^{\circ} \mathrm{C} / \mathrm{min}$ and then held isothermal $(20 \mathrm{~min})$; injector temperature: $250^{\circ} \mathrm{C}$ (injection mode: split $1 / 60$ ); detector temperature: $250^{\circ} \mathrm{C}$; carrier gas: helium.

GC/MS: GC-MS was performed with a Hewlett-Packard 6890 gas chromatograph, equipped with a polydimethylsiloxane fused-silica column $(30 \mathrm{~m} \times 0.25 \mathrm{~mm}$ i.d., film thickness $0.25 \mu \mathrm{m}$, HP19091Z-433.) interfaced with a Hewlett-Packard mass selective detector 5973 operated by HP Enhanced ChemStation software, version A.03.00. The oven temperature was programmed from 70 to $220^{\circ} \mathrm{C}$ at $3^{\circ} \mathrm{C} / \mathrm{min}$ and then held isothermal $(15 \mathrm{~min})$; injector temperature: $250^{\circ} \mathrm{C}$; carrier gas: helium, adjusted to a linear velocity of $30 \mathrm{~cm} / \mathrm{s}$; split $1 / 40$; interface temperature: $250^{\circ} \mathrm{C}$; MS source temperature: $230^{\circ} \mathrm{C}$; MS quadrupole temperature: $150^{\circ} \mathrm{C}$; ionization energy: $70 \mathrm{eV}$; ionization current: $60 \mu \mathrm{A}$; scan range: $35-350 \mathrm{u}$; scans/s: 4.51 .

${ }^{13} C$ NMR spectra: NMR spectra were recorded on a Bruker AC 200 Fourier transform spectrometer, operating at $50.323 \mathrm{MHz}$, equipped with a $10 \mathrm{~mm}$ probe in deuterated chloroform (around $200 \mathrm{mg}$ of oil in $2 \mathrm{~mL}$ of $\mathrm{CDCl}_{3}$ ), with all shifts $(\delta)$ referred to internal tetramethylsilane (TMS). Parameters: pulse width (PW): $5.0 \mu \mathrm{s}$ (flip angle $45^{\circ}$ ); acquisition time: $1.3 \mathrm{~s}$ and relaxation delay $D_{1}: 2 \mathrm{~s}$ (total recycling time $3.3 \mathrm{~s}$ ) for $32 \mathrm{~K}$ data table with a spectral width (SW) of $12500 \mathrm{~Hz}(250 \mathrm{ppm})$; composite phase decoupling (CPD) of the proton band; digital resolution: $0.763 \mathrm{~Hz} / \mathrm{pt} ; 5000$ scans were accumulated for each sample. An exponential multiplication of the free induction decay with the line broadening of $1.0 \mathrm{~Hz}$ was applied before Fourier transformation.

\subsection{Identification of components}

${ }^{13} \mathrm{C}$ NMR was carried out on the whole sample, without previous separation of the components, following the pioneering work done by Formàcek and Kubeczka (1982) and according to an experimental procedure and a computerized method developed in our laboratory (Tomi et al., 1995). The components were identified by comparison of the values of the carbon chemical shifts in the mixture spectrum with those of reference spectra compiled in a computerized data bank. Each compound is identified by taking into account three parameters, directly available from the computer program, (i) the number of observed signals with respect to that expected, (ii) the difference between the chemical shift of each signal in the mixture and in the reference $(\Delta \delta)$, (iii) the number of overlapped signals of carbons belonging to two components which possess fortuitously the same chemical shift. 
$G C$ : The components were identified by comparison of their retention indices on polar and apolar columns with those of authentic samples. Retention indices were determined relative to retention times of a series of $n$-alkanes with linear interpolation ("Target Compounds" software from Perkin-Elmer). The relative proportions of the essential oil constituents were expressed as percentages obtained by peak-area normalization and no correcting factor has been applied.

$G C / M S$ : Identification of the individual components was made by comparison of the acquired spectra with corresponding data from authentic samples or with literature data (Joulain and König, 1998; McLafferty and Stauffer, 1989) after a preliminary computer matching into a commercial mass spectra library.

\subsection{Data analyses}

The data were processed by Cluster Analysis using hierarchical clustering (Ward's technique and Euclidean distance measure) and were submitted to Discriminant Analysis, using the $x l$ STAT-Pro software (Thierry Fahmy, France).

\section{Results and discussion}

Fifty samples of essential oil obtained from plant material were analysed by GC, GC/MS and carbon-13 NMR. Sixty-one components accounting for 95.1 to $95.9 \%$ of

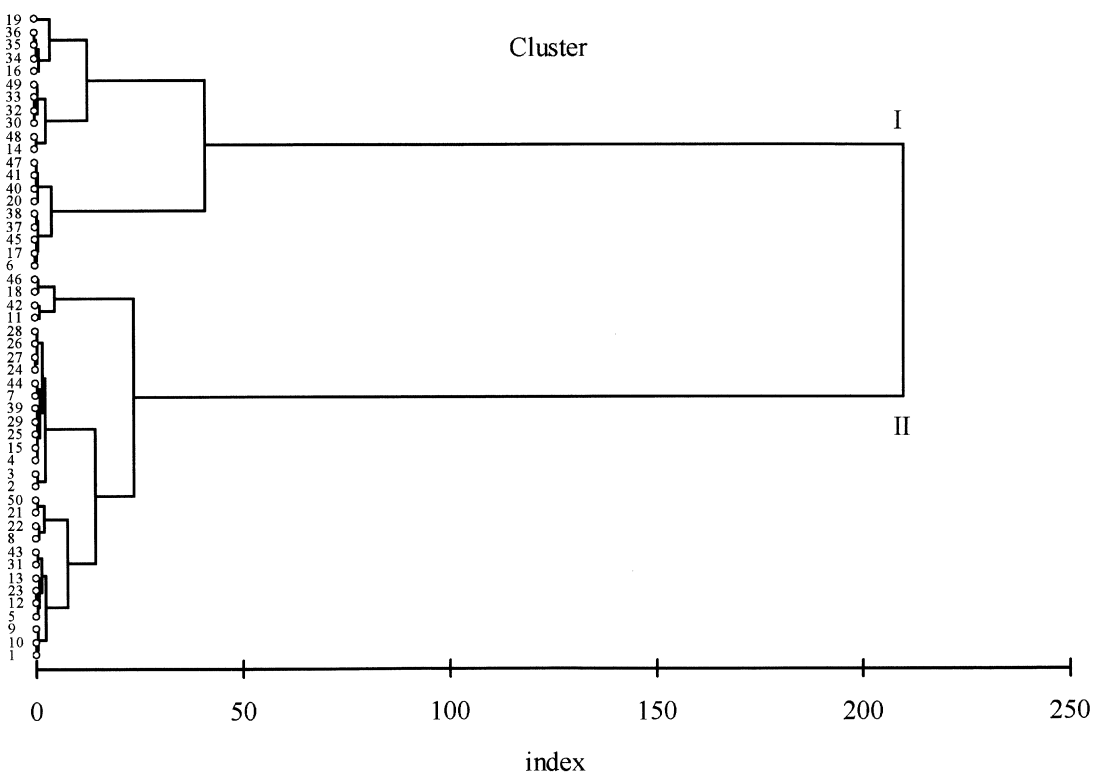

Fig. 2. Dendrogram obtained from the cluster analysis of 50 samples of Juniperus phoenicea subsp. turbinata from Corsica. Samples are clustered using Ward's technique with an Euclidean distance measure. 
the total oil were identified (Table 1). Thirty components over $0.4 \%$ representing from 80.3 to $95.8 \%$ of the whole chemical composition were taken into account for statistical analysis. The dendrogram (Fig. 2) suggested the existence of two clusters (clusters I and II). Discriminant analysis (DA) (Figs. 3 and 4) confirmed this clustering and the two-dimensional axial system originated in the DA distinguished the different types of essential oils based on the contents of $\alpha$-pinene, $\beta$-phellandrene and $\alpha$-terpinyl acetate.

The essential oils of cluster I ( $40 \%$ of the samples) are characterized by a high content of $\alpha$-pinene (mean 58.7\%, S.D. $=9.2$ ) (Fig. 5). The chemical composition of samples of cluster II ( $60 \%$ of the samples) is characterized by the weakest content of $\alpha$-pinene (mean 33.0\%, S.D. $=5.6$ ) and a significant content of $\beta$-phellandrene (mean $21.1 \%$, S.D. $=4.1$ ) and $\alpha$-terpinyl acetate (mean 8.2\%, S.D. $=4.6)($ Fig. 5). So, the leaf oils of $J$. phoenicea subsp. turbinata from Corsica exhibit a chemical variability with two clear composition patterns: $\alpha$-pinene and $\alpha$-pinene $/ \beta$-phellandrene $/ \alpha$-terpinyl acetate. Both composition patterns are present in all the stations with different ratios although no relation between the composition of the oils and the habitat can be established. For instance, samples from Barcaggio and Ajaccio stations exhibit a ratio of cluster I/cluster II = 1/9 while samples from from Porto-Vecchio have a repartition of cluster $\mathrm{I} /$ cluster $\mathrm{II}=7 / 1$ although all these plants grow on sands (coastal foredunes). Conversely, samples from Bonifacio are equally distributed in the two clusters (cluster $\mathrm{I} /$ cluster $\mathrm{II}=5 / 5$ ), all plants occurring on cliffs. The compositions of two representative samples belonging to clusters I and II, respectively, are reported in Table 1.

The mean chemical composition determined for cluster II is close to those reported for oils of subspecies turbinata from Spain and Portugal (named eu-mediterranea in the

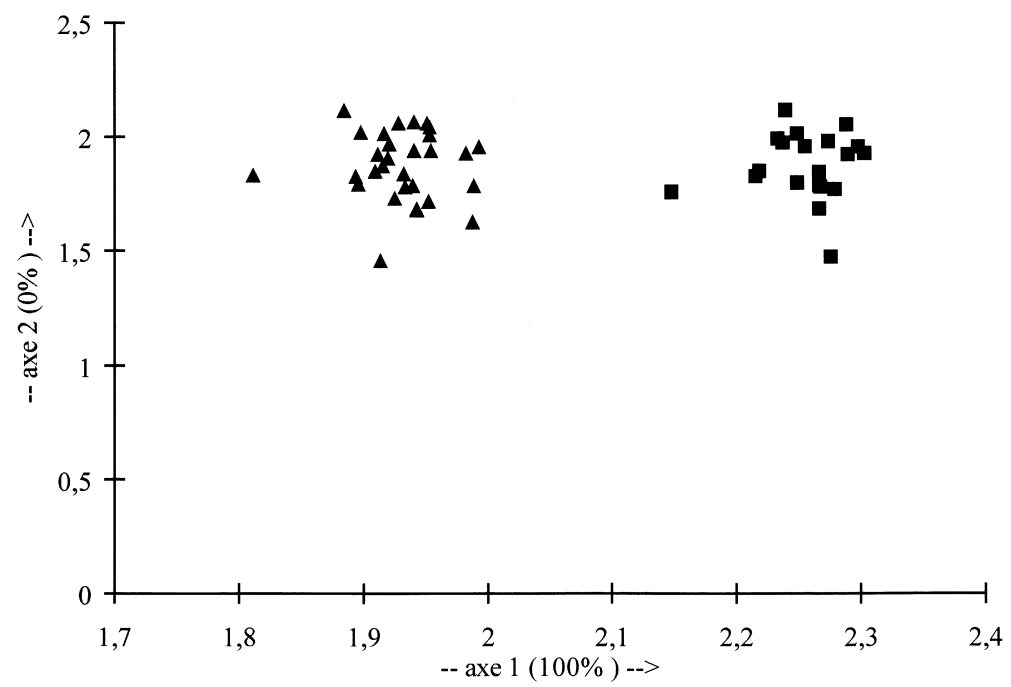

Fig. 3. Discriminant analysis scatterplot of 50 samples of Juniperus phoenicea subsp. turbinata from Corsica. (ם) Cluster I, ( $\mathbf{\Delta})$ Cluster II. 


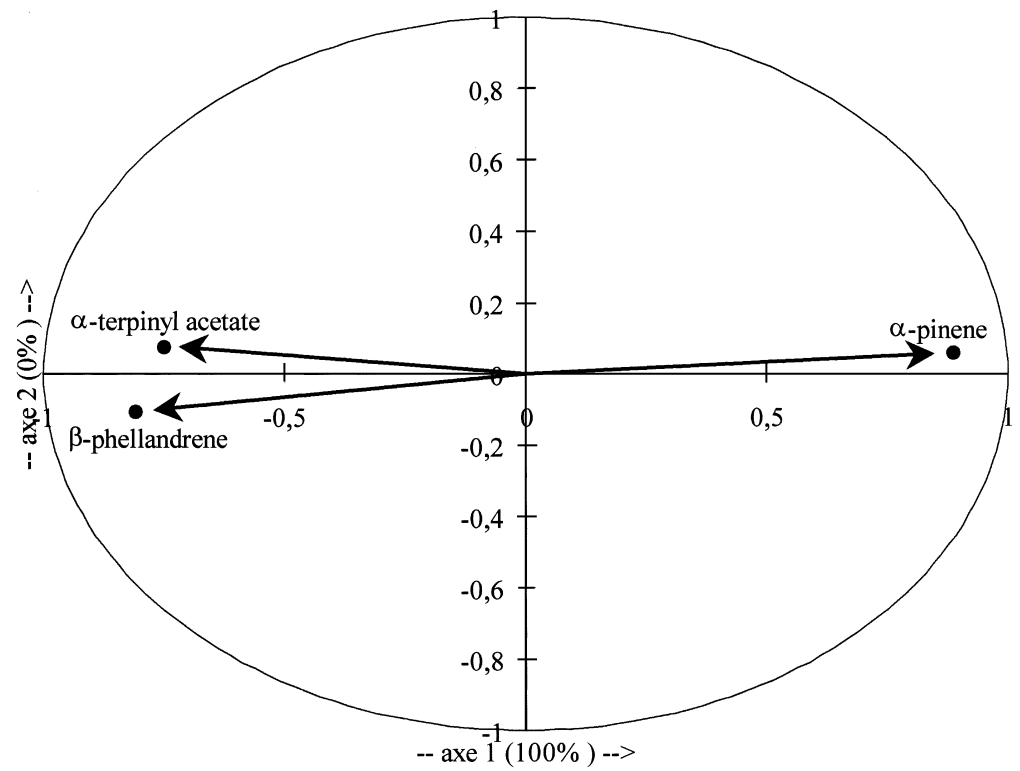

Fig. 4. Discriminant analysis scatterplot of the oil constituents.
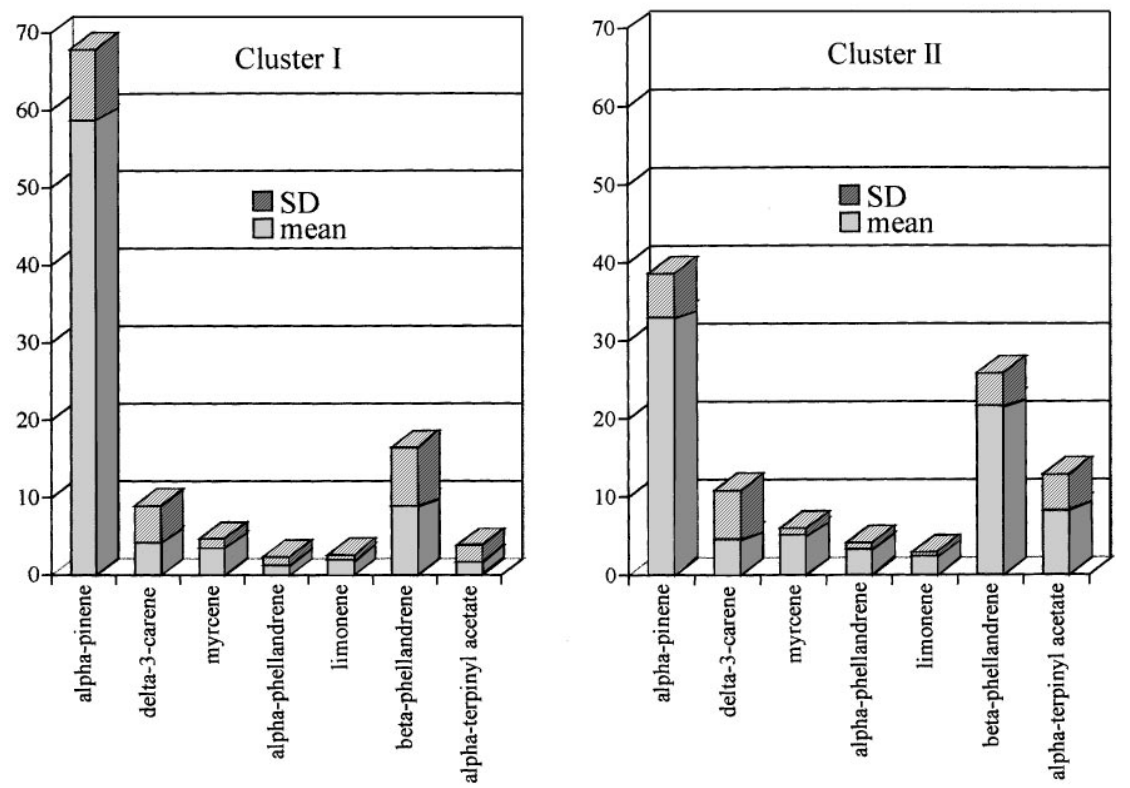

Fig. 5. Grey: mean percentage of major components, crosshatched: standard deviation. 
Table 1

Chemical composition of two representative samples of Juniperus phoenicea subsp. turbinata leaf oil from Corsica $^{a}$

\begin{tabular}{|c|c|c|c|}
\hline Constituents & BP-1 & Sample 35 (Cluster I) & Sample 15 (Cluster II) \\
\hline Tricyclene & 920 & 0.2 & 0.1 \\
\hline$\alpha$-Pinene & 931 & 59.5 & 31.1 \\
\hline Camphene & 943 & 0.3 & 0.2 \\
\hline$\beta$-Pinene & 970 & 1.0 & 1.2 \\
\hline Myrcene & 979 & 3.2 & 6.1 \\
\hline 2-Carene & 996 & 0.1 & 0.4 \\
\hline$\alpha$-Phellandrene & 997 & 0.4 & 4.0 \\
\hline$\Delta$-3-Carene & 1005 & 6.5 & 3.1 \\
\hline$\alpha$-Terpinene & 1008 & 0.1 & 0.2 \\
\hline p-Cymene & 1011 & 1.0 & 1.0 \\
\hline Limonene & 1020 & $1.5^{\mathrm{b}}$ & $2.2^{\mathrm{b}}$ \\
\hline$\beta$-Phellandrene & 1021 & $4.9^{\mathrm{b}}$ & $23.8^{b}$ \\
\hline$\gamma$-Terpinene & 1047 & 0.4 & 0.3 \\
\hline Octanol & 1052 & $\operatorname{tr}$ & - \\
\hline Fenchone & 1066 & 0.2 & 0.1 \\
\hline Cymenene & 1071 & 0.1 & - \\
\hline Terpinolene & 1078 & 0.6 & 1.8 \\
\hline Linalool & 1081 & 0.4 & - \\
\hline cis-Rose oxide & 1096 & $\operatorname{tr}$ & $\operatorname{tr}$ \\
\hline$\alpha$-Campholenal & 1102 & 0.4 & 0.1 \\
\hline 2-Cyclohexen-1-ol & 1106 & - & 0.4 \\
\hline Camphor & 1123 & 0.6 & - \\
\hline Trans-Pinocarveol & 1125 & 0.1 & - \\
\hline cis-Verbenol & 1127 & 0.4 & 0.4 \\
\hline Iso-Borneol & 1142 & - & 0.1 \\
\hline$p$-Mentha-1,5-dien-8-ol & 1143 & 0.3 & 0.1 \\
\hline Borneol & 1148 & 0.4 & - \\
\hline Cryptone & 1157 & 0.2 & 0.3 \\
\hline$p$-Cymene-8-ol & 1158 & - & 0.2 \\
\hline Terpinen-4-ol & 1161 & 0.1 & 0.3 \\
\hline$\alpha$-Terpineol & 1172 & 0.7 & 2.4 \\
\hline Verbenone & 1184 & 0.1 & 0.1 \\
\hline trans-Piperitol & 1187 & - & 0.1 \\
\hline trans-Carveol & 1207 & 0.2 & 0.1 \\
\hline Citronellol & 1208 & 0.1 & 1.1 \\
\hline Geraniol & 1232 & - & 0.1 \\
\hline Piperitone & 1233 & 0.1 & 2.6 \\
\hline Linalyl acetate & 1240 & 0.1 & 0.5 \\
\hline Iso-Pulegyl acetate & 1268 & - & 0.3 \\
\hline$\alpha$-Terpinyl acetate & 1332 & - & 9.8 \\
\hline$\alpha$-Cubebene & 1350 & 0.1 & - \\
\hline$\alpha$-Copaene & 1379 & 0.2 & - \\
\hline$\beta$-Bourbonene & 1386 & 0.1 & - \\
\hline$\beta$-Elemene & 1388 & 0.2 & - \\
\hline E-Caryophyllene & 1424 & 1.1 & 0.2 \\
\hline$\alpha$-Humulene & 1453 & 0.7 & $\operatorname{tr}$ \\
\hline$\alpha$-Amorphene & 1470 & 0.8 & - \\
\hline Germacrene D & 1478 & 0.9 & 0.2 \\
\hline
\end{tabular}


Table 1 (continued).

\begin{tabular}{lccc}
\hline Constituents & BP-1 & Sample 35 (Cluster I) & Sample 15 (Cluster II) \\
\hline Bicyclosesquiphellandrene $^{\mathrm{c}}$ & 1489 & 1.1 & $\mathrm{tr}$ \\
$\alpha$-Muurolene $^{- \text {tr }}$ & 1494 & $\mathbf{0 . 4}$ & $\mathrm{tr}$ \\
$\gamma$-Cadinene & 1508 & $\mathbf{0 . 6}$ & $\mathrm{tr}$ \\
$\delta$-Cadinene & 1516 & $\mathbf{1 . 0}$ & 0.2 \\
cis-Calamenene $_{\text {Elemol }}$ & 1519 & 0.3 & $\mathrm{tr}$ \\
Germacrene B & 1533 & 0.1 & 0.1 \\
Caryophyllene oxide & 1554 & 0.1 & 0.1 \\
Humulene epoxide & 1576 & $\mathbf{0 . 6}$ & - \\
Epi-Cubenol & 1582 & 0.4 & 0.1 \\
$\tau$-Muurolol & 1618 & $\mathbf{1 . 5}$ & - \\
$\alpha$-Cadinol & 1638 & 0.1 & 0.2 \\
Manoyl oxide & 1640 & 0.3 & -
\end{tabular}

${ }^{\mathrm{a}}$ Components were identified by GC-retention indices on two columns, GC/MS and ${ }^{13} \mathrm{C}$ NMR (bold numbers). Compositional values less than $0.05 \%$ are denoted as trace (tr). Order of elution and percentages of individual components are given in BP-1 column.

${ }^{\mathrm{b}}$ Order of elution and percentages of individual components are given in BP 20 column.

${ }^{\mathrm{c}}$ Correct epimer not identified.

last case) (Adams et al., 1996). The mean chemical composition of the samples belonging to cluster I ( $\alpha$-pinene-rich oils not yet reported for $J$. phoenicea subsp. turbinata) is close to those reported for $J$. phoenicea (sensu stricto) oils from Greece and Spain (Adams et al., 1996) and for J. phoenicea (subspecies not specified) oils (Gil de Meister and Hoffman, 1956; Banthorpe et al., 1973).

These results can be explained as follows. If only the subspecies turbinata occurs in Corsica, then this taxon exhibits chemical variability. However, from our results, we cannot exclude the presence of two subspecies growing in the same habitat and insufficiently differentiated by botanical features.

\section{Acknowledgements}

We thank Prof. J. Paiva, University of Coimbra, and Dr. G. Paradis, University of Corsica, for their invaluable help on J. phoenicea taxonomy. We thank the Collectivité Territoriale de Corse and ADEME (France) for a research grant; the JNICT (Portugal) and CNRS (France) for travel grants.

\section{References}

Adams, R.P., 1999. Systematics of multi-seeded Eastern Hemisphere Juniperus based on leaf essential oils and RAPD DNA fingerprinting. Biochem. Systems Ecol. 27, 709-725.

Adams, R.P., 1991. Cedar wood-oil-Analysis and properties. In: Linskins, H.F., Jackson, J.F. (Eds.), Modern Methods of Plant Analysis: Oils and Waxes. Springler, Berlin, pp. 159-173.

Adams, R.P., Barrero, A.F., Lara, A., 1996. Comparisons of the leaf essential oils of Juniperus phoenicea, J. phoenicea subsp. eu-mediterranea Lebr. \& Thiv. and J. phoenicea var. turbinata (Guss) Parl. J. Essent. Oil Res. 8, 367-371. 
Banthorpe, D.V., Davies, H.S., Gatford, C., Williams, S.R., 1973. Monoterpene patterns in Juniperus and Thuja species. Planta Med. 23, 64-69.

Bonnier, G., Douin, R., 1990. La grande flore. Belin, Paris.

Chalchat, J.C., Garry, R.P., Michet, A., Peyron, L., 1990. Chemical composition of natural and empyreumatic oils and extracts from Juniperus oxycedrus and Juniperus phoenicea wood. J. Essent. Oil Res. 2, 231-236.

Dawidar, A.M., Ezmirly, S.T., Abdel-Mogib, M., 1991. Sesquiterpenes and diterpenes from Juniperus phoenicea L. Pharmazie 46, 472-473.

De Pascual Teresa, J., San Feliciano, A., Tabernero, M.L., Miguel Del Corral, J.M., Barrero, A.F., Grande, M., 1978a. Components of the berries of Juniperus phoenicea L. I. Acid fraction. An. Quím. 74, 459-464.

De Pascual Teresa, J., San Feliciano, A., Tabernero, M.L., Barrero, A.F., 1978b. Components of the berries of Juniperus phoenicea L. II. Neutral fraction. An. Quím. 74, 465-469.

De Pascual Teresa, J., Barrero, A.F., Caballero, M.C., Ramos, M.A., San Feliciano, A., 1981. Componentes de las arcestidas de Juniperus phoenicea Linnaeus aceite esencial. Riv. Ital. EPPOS. 62, 353-354.

Falchi Delitala, L., 1980. Ricerche chemiotassonomiche sul genere Juniperus Linnaeus. Riv. Ital. EPPOS. 62, 303-309.

Fernandes-Costa, A., Cardoso do Vale, J., 1953-1954. Subsídios para o estudo das plantas aromáticas portuguesas, Essência de Juniperus phoenicea L. Bol. Fac Farm. Coimbra 13-14, 57-67.

Formàcek, V., Kubeczka, K.H., 1982. Essential Oils Analysis by Capillary Gas Chromatography and Carbon-13 NMR Spectroscopy. Wiley, Chichester.

Franco, J.A., 1964. Juniperus L. In: Tutin, T.G., Burges, N.A., Chater, A.O., Edmondson, J.R., Heywood, V.H., Moore, D.M., Valentine, D.H., Walters, S.M., Webb, D.A. (Eds.), Flora Europaea, Vol. 1. Cambridge University Press, UK, pp. 46-48.

Gil de Meister, E., Hoffman, Fr., 1956. Die Atherischen Öle, Vol. 4. Akademie-Verlag, Berlin, pp. 296-297.

Joulain, D., König, W.A., 1998. The Atlas of Spectral Data of Sesquiterpene Hydrocarbons. E.B.-Verlag, Hamburg.

Lawrence, B.M., 1989. Juniperberry oil. Essential Oils (1987-1988). Allured Publishing Corporation, Wheaton, pp. 240-241.

Lebreton, P., Thivend, S., 1981. Sur une sous-espèce du genévrier de phoenicie Juniperus phoenicea L., définie à partir de critères biochimiques, Naturali monspeliensia. ser. Bot., 47, 1-12.

Lebreton, P., 1983. Nouvelles données sur la distribution au Portugal et en Espagne de sous-espèces du genévrier de phoenicie (Juniperus phoenicea L.). Agronomia lusit 42, 55-62.

McLafferty, F.W., Stauffer, D.B., 1989. The Wiley/NBS Registry of Mass Spectral Data. Wiley, New York.

Paradis, G., 1991. Les formations à Juniperus phoenicea et à Juniperus oxycedrus subsp. macrocarpa sur le littoral de la Corse. Colloques phytosociol. XX, 345-358.

Proença da Cuhna, A., Roque, O.R., Cardoso do Vale, J., 1977. Novos ensaios na essência de Juniperus phoenicea L. Bol. Fac. Farm. Coimbra. 2, 9-23.

San Feliciano, A., Medarde, M., Tome, F., Miguel Del Corral, J.M., 1988. Acidos sandaracopimarico e isopimarico en diferentes poblaciones de Juniperus phoenicea L. An. Quím. 84, 360-363.

San Feliciano, A., Miguel Del Corral, J.M., Gordaliza, M., Salinero, M.A., 1992. Diterpenoides neutros y compuestos aromaticos de las hojas de Juniperus phoenicea subsp. turbinata. An. Quím. 88, 512-516.

San Feliciano, A., Miguel de Corral, J.M., Gordaliza, M., Salinero, M.A., Del Rey, B., 1993. Acidic constituents of Juniperus phoenicea subsp. turbinata leaves. Fitoterapia 64, 185-186.

Tabacik, C., Laporthe, Y., 1971. Diterpenes of Juniperus phoenicea. Major constituents. Phytochemistry 10, 2147-2153.

Tabacik, C., Poisson, C., 1971. Juniperus phoenicea diterpenes. Minor constituents. Phytochemistry 10, 1639-1645.

Tomi, F., Bradesi, P., Bighelli, A., Casanova, J., 1995. Computer-aided identification of individual components of essential oils using carbon-13 NMR spectroscopy. J. Magn. Reson. Anal. 1, 25-34.

Vidrich, V., Michelozzi, M., 1993. Sulla resa e compozione stagionale di olio essenziale di galbule e foglie di Juniperus phoenicea L. Italia Forestale e Montana, 48, 133-140. 